PALAEONTOLOGY

Mammalian Evolution

from our Vertebrate Palaeontology Correspondent

THE nineteenth symposium on vertebrate palaeontology and comparative anatomy was held at Bristol on September 28-29, followed by two days of field excursions. The evolution of mammals, especially those of Africa, was a principal theme, because there is a large and active group at Bristol concerned with this subject. New work on the earliest known mammals, Eozostrodon/ Morganucodon and Kuehneotherium, of the Triassic was described by Professor A. W. Crompton (Harvard University). Some workers have suggested that each of these two mammals gave rise to some of the groups of Jurassic mammals, but that they are so different from one another that they must have arisen from different lines of advanced mammal-like reptile-so making the mammals diphyletic. Professor Crompton strongly dissented from this view, pointing out a number of similarities between the two Triassic genera. $\mathrm{He}$ also noted that the epipterygoid of such cynodonts as Probainognathus is not greatiy enlarged, indicating that this group could be ancestral to all the mammals, including the triconodonts (whose epipterygoid, unlike that of most other mammals, is small). An interesting discovery of early mammals in Britain was that of $\mathrm{Dr} \mathbf{M}$. Waldman (Stowe School). Though difficult to detect, and also difficult to remove from the hard matrix, his find of Middle Jurassic mammals in the Isle of Skye is of great potential interest, because the only other mammalian fauna of this age comes from the Stonesfield Slate of Oxford, which is no longer quarried.

Professor P. M. Butler (Royal Holloway College, London) suggested that the directions of jaw movement, as indicated by wear striations on the teeth, had passed through three principal phases in mammalian evolution. In Jurassic forms, the movement is partly transverse and becomes progressively more so, but the teeth shear past one another. Not until the Cretaceous do the teeth collide at the end of the jaw movement, so giving a crushing action. This in turn provided the possibility of a subsequent movement in another direction, so that two different sets of facets can be distinguished in the Tertiary herbivores and omnivores.

The studies of African mammals ranged from the problems of the phylogeny of the older forms to those of evolutionary rates and the comparison of later forms with those still extant. Mr G. J. Heal (University of Bristol) described sirenians which showed that two families of this order were already distinguishable in the Eocene, and $\mathrm{Mr}$
A. W. R. Wight (University of Bristol) described new specimens of Proboscidea and discussed the Eocene stratigraphy of Libya. Dr V. Maglio (Princeton University) analysed the rates of appearance and replacement of species in the Elephantinae and suggested that the group was in the middle of a phase of adaptive radiation when, in the Upper Pleistocene, there was a dramatic crash from eleven lineages to the present two. Dr A. W. Gentry (British Museum (Natural History)) compared the African Pleistocene antelopes with those of the continent today and pointed out that, because horn shape is a species recognition feature, the whole antelope fauna of any one time, within which such distinctions were essential, should be considered in any analysis.

At the other end of the chordate evolutionary story, Dr R. P. S. Jefferies (British Museum (Natural History)) described a new mitrate echinoderm which he believed showed evidence of being ancestral to the cephalochordates. Professor D. L. Dineley (University of
Bristol) gave an interesting account of the Late Devonian fish fauna of Escuminac Bay, Canada, and Mr D. S. Broad (University of Bristol) described new heterostracans from Arctic Canada which showed evidence of the growth of each plate by accretion around a small number of original tubercles. The problem of interpreting the patterns of tetrapod tooth replacement was discussed by Dr R. DeMar (Liberal Arts College, Chicago), who showed that Edmund's Zahnreihe is only one of a number of theoretically possible alternatives, and that computer studies can show why some of these are not acceptable, because they lead to lengthy gaps in the tooth row.

Dr A. C. Charig (British Museum (Natural History)) pointed out that reptiles colonized more new ways of life in the Triassic than ever before or since, and suggested that this might be more than mere coincidence-though other possible reasons were not obvious. A valuable approach to the study of pterosaurs was presented by Dr G. R.

\title{
Visualizing Agglutinin Sites on Cell Surfaces
}

DURING the past several months the suggestion that transformed cells are more readily agglutinated by plant agglutinins than their untransformed counterparts because transformation leads to an increase in the number of agglutinin-binding sites exposed on the cell surface has been abandoned. For experiments such as those reported by Cline and Livingston and Ozanne and Sambrook in Nature New Biology (232, 155,156 ; 1971) have shown that there is apparently no significant difference between the numbers of these binding sites on the surfaces of transformed and untransformed cells. These workers have suggested therefore that it is the distribution of agglutinin-binding sites rather than their numbers which is changed by transformation and in next Wednesday's Nature New Biology, Nicholson reports observing in the electron microscope just such a change; after transformation by SV40 virus the concanavalin A binding sites on the surface of mouse 3T3 cells are clustered whereas before transformation they are dispersed.

Nicholson was able to make these most elegant observations by preparing ferritin conjugated concanavalin $\mathrm{A}$ and then devising a new technique for preparing the cell surface membrane for electron microscopy. His technique involves first "strengthening" the cell membrane by briefly incubating the cells in 0.1 per cent formaldehyde before lysing them on an air-water interface and then picking up the membrane on electron microscope grids. Once on the grids the membranes can then be stained with the ferritin tagged concanavalin A.

The micrographs of stained membranes from transformed and untransformed 3T3 cells reveal at a glance the striking difference in distribution of binding sites. Single ferritin tagged concanavalin A molecules are randomly distributed on the membranes of the untransformed cells. By contrast the tagged concanavalin A molecules are in clusters, which are randomly distributed, on the membranes of the cells transformed by SV40. Although there are some 3 to 3.5 times more molecules of bound concanavalin A per unit area of transformed than per unit area of untransformed cell membrane, Nicholson points out that the total surface area of the transformed cells is only about half that of their untransformed counterparts.

Nicholson has also shown that after exposure to weak trypsin solutions, the concanavalin A sites on the surface of untransformed cells tend to be clustered, but within a few hours of enzyme treatment the sites assume their normal distribution.

There could therefore scarcely be a clearer demonstration of the fact that transformation causes a change in the distribution of these agglutinin-binding sites, which presumably accounts for the increased susceptibility of these transformed cells to agglutination. Whether this particular surface change also alters the social behaviour of cells remains to be seen. 